\title{
Efek Imunostimulasi Ekstrak Etanol Umbi Iles-iles Terhadap Aktivitas Fagositosis Sel Makrofag pada Tikus Putih Strain Wistar yang Diinokulasi Staphylococcus aureus
}

\author{
Arfatul Makiyah, ${ }^{1}$ Usep Abdullah Husin, ${ }^{2}$ Ramlan Sadeli ${ }^{2}$ \\ ${ }^{1}$ Universitas Muhammadiyah Sukabumi, ${ }^{2}$ Departemen Mikrobiologi dan Parasitologi Fakultas Kedokteran \\ Universitas Padjadjaran/Rumah Sakit Dr. Hasan Sadikin Kota Bandung
}

\begin{abstract}
Abstrak
Penelitian ini dilakukan untuk menguji aktivitas makrofag, karena makrofag berperan penting dalam respons imun dan untuk menganalisis aktivitas fagositosis karena efek flavonoid dan polisakarida umbi iles-iles pada respons imun tersebut. Tujuan penelitian ini adalah menganalisis efek imunostimulasi ekstrak etanol umbi ilesiles terhadap aktivitas fagositosis sel makrofag pada tikus putih strain Wistar yang diinokulasi Staphylococcus aureus. Penelitian ini merupakan studi eksperimental laboratorium rancang acak lengkap terhadap tikus putih strain Wistar. Penelitian ini dilaksanakan di Laboratorium Patologi Klinik RSUP Dr. Hasan Sadikin Bandung dan dilaksanakan bulan Januari-Maret 2012. Tikus putih strain Wistar sebanyak 30 ekor dibagi menjadi 5 kelompok. Tikus putih strain Wistar pada setiap perlakuan diberikan secara oral selama 7 hari pada tanggal 1-7 Januari 2012. Parameter efek imunostimulan ekstrak etanol umbi iles-iles terhadap aktivitas makrofag secara mikroskopis adalah peningkatan jumlah makrofag, indeks fagositosis, dan secara makroskopis adalah peningkatan indeks hati, limpa, serta timus. Secara mikroskopis melalui gambaran makrofag yang dinilai setelah 1, 3 jam, dan 6 jam inokulasi $S$. aureus. Hasil penelitian menunjukkan bahwa jumlah makrofag pada kelompok ekstrak etanol umbi iles-iles dosis $220 \mathrm{mg} / \mathrm{kgBB}$ pada perlakuan setelah 1, 3, dan 6 jam lebih tinggi dibanding dengan kelompok ekstrak etanol umbi iles-iles dosis $110 \mathrm{mg} / \mathrm{kgBB}$ dan $55 \mathrm{mg} / \mathrm{kgBB}(\mathrm{p}<0,05)$, begitu juga jika dibanding dengan kelompok pembanding Zymosan A dan kontrol $(\mathrm{p}<0,05)$. Simpulan, ekstrak etanol umbi iles-iles (Amorphophallus variabilis BL.) memiliki efek imunostimulan dan memiliki efektivitas peningkatan respons imun lebih baik dibanding dengan kontrol pembanding zymosan A 35 mg/kgBB. [MKB. 2016;48(2):68-77]
\end{abstract}

Kata kunci: Ekstrak etanol, indeks fagositosis, indeks hati, makrofag, umbi iles-iles

\section{The Effect of Iles-iles Tubers Ethanol Extract Immunostimulant on Macrophages Cell Phagocytic Activities in Wistar Strain White Rat Inoculated by Staphylococcus aureus}

\begin{abstract}
This study was conducted to test the activity of macrophages based on the notion that macrophages play an important role in the immune response. This study analyzed the phagocytic activities due to the effects of flavonoids and polysaccharides iles-iles tubers in the immune response. The aim of this study was to analyze the immunostimulation effect of iles-iles tubers ethanol extract on phagocytic activities of macrophages in Wistar strain white rat inoculated with Staphylococcus aureus. This study used a complete randomized design with wistar strain white rat. This study was conducted at the Clinical Pathology Laboratory of Dr. Hasan Sadikin General Hospital from January-March 2012. Wistar strain white rats $(n=30)$ were divided into 5 groups. Wistar strain white rats in each treatment group were given treatment that was administered orally for 7 days from 1-7 January 2012. The result shows that the number of macrophages in iles-iles tubers ethanol extract group that received $220 \mathrm{mg} / \mathrm{kgBW}$ dose after 1 hour, 3 hours, and 6 hours of treatment was higher than that of the tuberiles iles ethanol extract that received $110 \mathrm{mg} / \mathrm{kgBW}$ and $55 \mathrm{mg} / \mathrm{kgBW}(\mathrm{p}<0.05)$, both for Zymosan A comparison group and control group $(\mathrm{p}<0.05)$. Conclusion of this study is iles-iles tubers ethanol extract (Amorphophallus variabilis BL.) is effective for immune-stimulatory healing activity and has better effectiveness for improving immune response compared to zymosan A 35 mg/ kgBW. [MKB. 2016;48(2):68-77]
\end{abstract}

Key words: Ethanol extract, iles-iles tubers, liver index, macrophages, phagocytic index

Korespondensi: Arfatul Makiyah, S.Pd., M.Kes, Program Studi D-3 Keperawatan Universitas Muhammadiyah Sukabumi, mobile 081808025866, e-mail arfa.makiyah.spd.mkes@gmail.com 


\section{Pendahuluan}

Salah satu bagian dari budaya bangsa Indonesia yang berkaitan dengan pemanfaatan kekayaan alam, yaitu penggunaannya untuk pemeliharaan kesehatan dan pengobatan serta penyakit. Budaya didapatkan dari pengalaman secara turun-temurun. Aneka ragam tumbuhan di alam sekitar dapat memberikan manfaat kesehatan bagi penggunanya yang terus dikembangkan lebih lanjut dan juga diwariskan secara turuntemurun antargenerasi sehingga obat tradisional dapat dimanfaatkan sampai dengan sekarang. ${ }^{1}$ Seiring perkembangan zaman yang semakin canggih seperti sekarang ini, pemakaian dan pendayagunaan obat tradisional di Indonesia mengalami kemajuan yang pesat. Kemajuan teknologi yang canggih dapat mengolah obat tradisional lebih praktis, enak, dan menarik. Masyarakat beranggapan bahwa obat tradisional dapat digunakan sebagai pengobatan alternatif selain obat-obat modern. ${ }^{2}$

Iles-iles (Amorphophallus variabilis BL.) tergolong marga Amorphophallus dan termasuk ke dalam suku talas-talasan (Araceae). Tanaman umbi iles-iles merupakan salah satu tanaman yang digunakan sebagai obat alami. Umbi ilesiles berkhasiat sebagai obat bisul, luka iris dan luka karena gigitan binatang berbisa. Umbi iles-iles memiliki kandungan kimia, yaitu air, glukomanan, saponin, flavonoid, pati, protein, lemak, serat kasar, dan juga kalsium oksalat; sedangkan daun iles-iles mempunyai kandungan kimia, yaitu tanin. Kandungan kimia alami yang terdapat pada umbi iles-iles yang mempunyai aktivitas anti-inflamasi dan memacu aktivitas makrofag sehingga dapat meningkatkan sistem kekebalan tubuh adalah flavonoid, saponin, dan polisakarida. ${ }^{3}$ Mengingat pemanfaatannya yang cukup luas spektrumnya terutama pada penyakit infeksi, diduga efek yang ditimbulkan adalah efek positif sebagai imunostimulator. ${ }^{4}$

Untuk menguji hal itu, penelitian dilakukan untuk melihat pengaruhnya pada peningkatan aktivitas makrofag. ${ }^{5}$ Penelitian ini untuk menguji aktivitas makrofag karena makrofag berperan penting dalam suatu respons imun, bukan hanya untuk respons imun innate, tetapi juga untuk menginduksi respons imun adaptive. Makrofag adalah fagosit yang merupakan suatu antigen presenting cells (APC) yang pertama diketahui. Makrofag dapat ditemukan dalam sirkulasi maupun dalam jaringan. ${ }^{6}$ Di antara sitokin yang dihasilkan adalah interleukin-1 (IL-1) yang diperlukan untuk memacu proliferasi sel $\mathrm{T}$ dan $B$ faktor pertumbuhan fibroblas dan endotel vaskular yang diperlukan untuk dapat perbaikan jaringan yang rusak..$^{7,8}$

Sel-sel makrofag berperan penting di dalam sistem pertahanan tubuh karena kemampuan fagositosis bakteri dan menghasilkan berbagai mediator inflamasi. ${ }^{9}$ Sel-sel efektor yang terlibat di dalam proses inflamasi akan melepaskan berbagai jenis substansi. Fungsi sel-sel efektor maupun substansi yang dilepaskannya dapat dihambat ataupun didorong oleh bahan-bahan imunomodulator, yaitu imunosupresor dan juga imunostimulator yang dapat diperoleh dari dalam maupun dari luar tubuh. Imunosupresor dari luar tubuh di antaranya dapat diperoleh dari tumbuhan obat. ${ }^{9,10}$

Berdasarkan hasil telaah literatur di atas dan belum terdapat penelitian pada ekstrak etanol umbi iles-iles ini maka akan diteliti efek imunostimulasi ekstrak etanol umbi ilesiles (Amorphophallus variabilis BL.) terhadap aktivitas fagositosis sel makrofag pada tikus putih (Rattus norvegicus) strain Wistar yang diinokulasi oleh Staphylococcus aureus. Efek imunostimulasi ekstrak umbi iles-iles berperan untuk melihat respons imun. Penentuan respons imun dengan cara mengukur jumlah makrofag dan aktivitas makrofag tersebut. Penelitian ini bertujuan menganalisis aktivitas fagositosis yang disebabkan efek flavonoid dan polisakarida pada respons imun ini. Hasil penelitian ini diharapkan dapat memberikan informasi dan gambaran kepada masyarakat mengenai batas keamanan ekstrak umbi iles-iles sehingga dapat dijadikan acuan untuk dapat digunakan selanjutnya dalam pemanfaatan umbi iles-iles sebagai obat. ${ }^{11}$

\section{Metode}

Penelitian bersifat eksperimental laboratorik dengan desain post test only control group design. Penelitian ini menggunakan hewan coba tikus putih galur strain Wistar dibagi menjadi 5 kelompok perlakuan. Penelitian ini dilaksanakan dengan menggunakan rancangan acak lengkap (RAL) dan dilaksanakan dengan 2 pengulangan, yaitu uji pertama dan uji kedua.

Subjek penelitian adalah 30 ekor tikus putih (Rattus novergicus) strain Wistar yang diperoleh dari Laboratorium Biofarma Bandung. Tikus putih harus diberikan suatu perlakuan adaptasi terhadap kondisi laboratorium yang akan digunakan sebelum diberikan perlakuan selama 7 hari pada tanggal 25-31 Desember 2011 di Laboratorium Farmakologi Fakultas Kedokteran Universitas Padjadjaran. Setelah masa adaptasi 
tikus tidak boleh melebihi bobot badan 250-300 gram atau sakit.

Tikus tersebut harus memenuhi kriteria inklusi sebagai berikut: tikus sehat yang memiliki ciri-ciri rambut tikus bersih dan tidak ada luka pada tubuhnya, tikus bergerak aktif, tikus galur Wistar berumur 2-3 bulan dan bobot badan 250-300 gram, kondisi sehat, dan tidak ada kelainan fisik. Kriteria eksklusi hewan coba tersebut sebelum dilakukan percobaan adalah sebagai berikut: penurunan bobot badan selama adaptasi di laboratorium selama 7 hari $>10 \%$ bobot badan awal dan terlihat sakit selama masa adaptasi di laboratorium. Kriteria drop out adalah tikus yang mati selama adaptasi dan perlakuan.

Bahan-bahan yang dipakai dalam penelitian ini adalah ekstrak etanol umbi iles-iles. Umbi iles-iles, hasil determinasi tanaman di Herbarium Bandungense Sekolah Ilmu dan Teknologi Hayati ITB dinyatakan bahwa tanaman tersebut adalah Amorphophallus variabilis BL. dari suku Araceae. Umbi Iles-iles sebagai bahan uji diambil dari perkebunan di daerah Depok dan Majalengka, Jawa Barat. Umbi yang dipilih adalah umbi iles-iles dewasa yang siap panen, kemudian dilakukan ekstraksi di Laboratorium Farmasi Institut Teknologi Bandung (ITB), akuades steril (aquabidest), $\mathrm{NaCl} \mathrm{0,9 \%} \mathrm{bebas} \mathrm{pirogen,} \mathrm{alkohol}$ $70 \%$ dan metanol absolut, antikoagulan EDTA dan larutan turk yang mengandung gentian violet $1 \%$ dalam air dan asam asetat glasial, larutan gyemsa modified solution 20\%, zymosan A (Z4250), larutan medium pertumbuhan makrofag in vivo hank (Hank's balanced salt solution), larutan fhosphate buffer saline (PBS) dan larutan chloroform sebagai anastesi pada saat hewan coba akan digunakan.

Alat yang dipergunakan dalam penelitian ini yaitu, perangkat alat pengukur berat (timbangan hewan, timbangan digital Agis (skala 0-2.000 gram) dengan ketelitian 0,01 gram), peralatan adaptasi hewan coba (kandang tikus, tempat minum tikus, feeding tube FR-5), peralatan alat pembuat ekstrak etanol umbi iles-iles (maserator, rotary evaporator, oven), peralatan pemberian ekstrak etanol umbi iles-iles secara oral (suntik oral $5 \mathrm{~mL}$ dengan jarum ukuran 18 gauge, botol untuk menyimpan dosis), peralatan kultur Staphylococcus aureus ATCC 25923 (ose/sengkelit, tabung reaksi, cawan petri, api bunsen, mikro pipet/pipet Eppendorf, pipet, alat pengukur kekeruhan McFarland 0.5), peralatan menghitung jumlah leukosit (tabung sampel darah Eppendorf, hemositometer, Sysmex XE 5000), peralatan pengambilan cairan peritoneal (peralatan bedah minor, erlenmeyer $500 \mathrm{~mL}$, spuit injeksi $1 \mathrm{~mL}, 3 \mathrm{~mL}, 5 \mathrm{~mL}$, dan $10 \mathrm{~mL}$ ), peralatan pembuatan preparat apusan makrofag (cover glass dan object glass, minyak imersi, sentrifugator $2.500 \mathrm{rpm}$ ), peralatan untuk menghitung dan melihat aktivitas sel makrofag adalah mikroskop cahaya (Olympus®) dengan perbesaran $1.000 \mathrm{x}$ dan LCD notebook serta peralatan dokumentasi, yaitu kamera digital.

Bakteri uji yang digunakan dalam penelitian ini adalah S. aureus ATCC 25923 yang diperoleh dari Laboratorium Mikrobiologi Unit Penelitian Kedokteran Fakultas Kedokteran Universitas Padjadjaran. Pemilihan sampel dilakukan dengan cara simple random sampling yang kemudian dibagi menjadi lima kelompok. Jumlah sampel minimal dihitung dengan menggunakan rumus Federer (r: jumlah sampel, t: jumlah perlakuan) $(\mathrm{r}-1)(\mathrm{t}-1) \geq 15$. Jumlah sampel minimal untuk setiap kelompok perlakuan harus lebih dari atau sama dengan 5. Hewan coba harus memenuhi kriteria sampai mencukupi jumlah sampel maka hewan yang dibutuhkan dalam penelitian ini 30 ekor.

Hewan coba yang digunakan dalam penelitian ini adalah tikus putih galur strain Wistar berusia 2-3 bulan, bobot badan 250-300 gram. Sebelum digunakan sebagai hewan coba, semua tikus putih dipelihara terlebih dahulu selama kurang lebih satu minggu untuk penyesuaian lingkungan, mengontrol kesehatan dan berat badan, serta menyeragamkan makanannya.

Umbi iles-iles yang telah dipilih dibersihkan dengan air mengalir yang bersih, kemudian diiris setipis-tipisnya dengan pisau stainless steel agar tidak terjadi reaksi kimia yang merugikan. Umbi iles-iles kemudian ditimbang sehingga diperoleh beratnya lalu umbi iles-iles tersebut dikeringkan pada ruangan yang tidak terkena cahaya matahari langsung selama 2 hari. Ciri khusus tanaman yang sudah kering adalah berat umbinya sudah berkurang $70-80 \%$ dari berat umbi segarnya dan disebut simplisia. Simplisia ini kemudian dihaluskan sehingga menjadi serbuk dengan alat grinding, kemudian ditimbang sehingga diperoleh beratnya sebelum diekstraksi.

Simplisia kemudian dimasukkan ke dalam maserator yang sudah diberikan alas kapas dan pelarut etanol, didiamkan selama 24 jam, kemudian dikeluarkan dari outlet maserator, dan disebut ekstrak encer. Tambahkan pelarut baru ke dalam ampas yang ada di dalam maserator, begitu seterusnya sampai pelarut yang keluar dari outlet maserator tidak berwarna lagi (biasanya setelah 5-6 kali rendaman). Ekstrak encer yang didapatkan lalu dipekatkan dengan 
mempergunakan alat rotary evaporator sampai pekat atau sampai tidak ada lagi pelarut yang menetes di kondensor rotary evaporator. Ekstrak pekat biasanya berbentuk pasta.

Dosis ini didapatkan hasil konversi dosis lazim pada manusia dengan perhitungan sebagai berikut: berat bersih simplisia umbi iles-iles 1.500 gram; berat bersih ekstrak etanol umbi ilesiles 41,6 gram ( $\pm 2 \%$ berat simplisia); Dosis lazim simplisia pada manusia per hari $3 \times 1$ sendok serbuk simplisia=3 x 10 gram=30 g simplisia; dosis ekstrak etanol umbi iles-iles pada manusia (70 kg) per hari $2 \%$ x $30 \mathrm{~g}$ simplisia 0,6 g ekstrak etanol umbi iles-iles; dosis ekstrak etanol umbi iles-iles pada tikus (200 mg) per hari 0,018 x 0,6 gram $=0,0108$ gram $=10,8 \mathrm{mg} \approx 11 \mathrm{mg}=55 \mathrm{mg} /$ $\mathrm{kgBB}$.

Bakteri uji yang digunakan dalam penelitian ini adalah S. aureus ATCC 25923 yang diperoleh dari Laboratorium Mikrobiologi Unit Penelitian Kedokteran Fakultas Kedokteran Universitas Padjadjaran. S. aureus ATCC 25923 dibiakkan pada media nutrien agar (NA) agar miring. ${ }^{12}$ Satu ose kultur $S$. aureus diinokulasi ke dalam media NA miring dengan cara menggores. Setelah itu diinkubasi dalam inkubator pada suhu $37^{\circ} \mathrm{C}$ selama 24 jam. $S$. aureus yang tumbuh pada media NA miring dipindahkan ke dalam kaldu pepton, diinkubasi 24 jam pada suhu $37^{\circ} \mathrm{C}$. $S$. aureus di-mixer selama 15 menit agar homogen, lalu terbentuk pelet dan diresuspensikan setara dengan kekeruhan larutan McFarland 0,5.

Tiga puluh ekor tikus dibagi menjadi lima kelompok perlakuan uji aktivitas fagositosis makrofag. Kemudian tikus diadaptasikan selama 7 hari dengan pemberian pelet agar tikus sehat. Penelitian dilaksanakan dengan uji pendahuluan dan juga uji sebenarnya. Kelompok perlakuan dilakukan selama 7 hari untuk melihat aktivitas fagositosis makrofag dengan pemberian ekstrak dilakukan secara oral dengan masing-masing perlakuan sebagai berikut: kelompok I (ekstrak etanol umbi iles-iles dosis $220 \mathrm{mg} / \mathrm{kgBB}$ ); kelompok II (ekstrak etanol umbi iles-iles dosis $110 \mathrm{mg} / \mathrm{kgBB}$ ); kelompok III (ekstrak etanol umbi iles-iles dosis $55 \mathrm{mg} / \mathrm{kgBB}$ ); Kelompok IV (kontrol positif menggunakan pembanding menggunakan zymosan A $35 \mathrm{mg} / \mathrm{kgBB}$ ) dan kelompok V (kontrol negatif menggunakan $5 \mathrm{~mL}$ akuades).

Seri dosis ekstrak etanol umbi iles-iles dibuat dengan melarutkan sejumlah x mg ekstrak etanol umbi iles-iles ditambahkan pelarut (larutan akuades sebanyak $5 \mathrm{~mL} /$ ekor tikus putih strain Wistar). Akuades dipergunakan sebagai kontrol pelarut maupun kontrol normal. Pada hari ke-7 tikus disuntik $S$. aureus secara intraperitoneal (i.p.) dengan dosis $10^{8} /$ tikus dalam $0,5 \mathrm{~mL}$ larutan fisiologis 0,9\%, kemudian dibiarkan dalam interval 1, 3, dan 6 jam.

Setelah pemberian ekstrak etanol selama 7 hari, kemudian dilakukan isolasi eksudat cairan peritoneal tikus dengan menyuntikkan medium larutan Hank's balanced salt solution ke dalam rongga perut tikus sebanyak $3 \mathrm{~mL}$, dan setelah selnya semua turun dari tabung, cairan tersebut disentrifus 2.500 rpm dalam 8-10 menit, dibuang supernatannya. Sel diendapkan terlebih dahulu, setelah itu dibuang supernatan yang masih bersisa. Suspensi supernatan diteteskan $\pm 0,5 \mathrm{~mL}$ diatas kaca preparat yang telah disiapkan, dibuat preparat apus dan difiksasi dengan metanol selama 5 menit, diwarnai dengan Gyemsa modified solution $20 \%$, dibilas dengan akuades kemudian dikeringkan. Preparat dilihat di bawah mikroskop cahaya dengan perbesaran $1.000 \mathrm{x}$. Aktivitas fagositosis ditetapkan berdasarkan persentase fagosit yang melakukan fagositosis dari 100-200 makrofag.

Tikus yang telah diberi ekstrak etanol umbi iles-iles selama 7 hari berturut-turut dibedah, kemudian tikus dieutanasi dan dibedah, lalu diambil hati, limpa, serta timusnya diisolasi dan ditimbang untuk ditentukan berapa persen indeks organnya. Kebermaknaan indeks organ kelompok uji terhadap kontrol yang ditentukan berdasarkan hasil olah statistik.

Setelah hasil penelitian terkumpul, kemudian dilakukan pengolahan data sesuai dengan urutan sebagai berikut: data yang diperoleh dari hasil uji aktivitas fagositik makrofag (penentuan indeks fagositik), indeks organ, persentase jumlah makrofag dari setiap kelompok telah terkumpul, analisis awal dilakukan pengujian distribusi data; dilakukan analisis data menggunakan uji ANOVA satu arah untuk melihat ada tidaknya perbedaan efek perlakuan yang diberikan antara kelompok kontrol positif, kontrol negatif, dan kelompok perlakuan (ekstrak etanol umbi iles-iles); jika hasil uji tersebut bermakna maka diteruskan dengan uji Duncan dengan taraf signifikansi 5\% $(\mathrm{p}<0,05)$. Untuk melengkapi hasil perbandingan antara kelima kelompok pengamatan, dibuat penggambaran grafik ke dalam diagram batang dan rata-rata setiap variabel.

Dalam penelitian ini dipergunakan hewan coba tikus putih galur strain Wistar untuk menggantikan manusia sebab zat atau alat baru tidak boleh digunakan untuk pertama kali pada manusia kecuali bila sebelumnya telah diuji pada hewan dan diperoleh kesan yang cukup mengenai keamanannya. Perlakuan hewan percobaan yang 
dipergunakan untuk penelitian kesehatan bagi manusia kebanyakan akan mengalami berbagai hal yang tidak akan menyenangkan bagi hewan tersebut, misalnya hewan akan mengalami suatu ketidaknyaman (inconvenience), ketidaksenangan (discomfort), tekanan (distress), rasa nyeri (pain), dan mengalami kematian (death). ${ }^{12}$ Dalam penelitian ini diterapkan suatu prinsip perlakuan pada hewan percobaan sesuai dengan suatu prinsip dasar pertimbangan etik penelitian kesehatan, yaitu prinsip 3R atau replacement, reduction, dan refinement. ${ }^{13}$

Penelitian ini dilaksanakan di Laboratorium Farmakologi Fakultas Kedokteran Universitas Padjadjaran, Laboratorium Mikrobiologi Unit Penelitian Kedokteran (UPK) FK Unpad/RSUP Dr. Hasan Sadikin Bandung, dan Departemen Patologi Klinik RSUP Dr. Hasan Sadikin Bandung. Penelitian dilaksanakan bulan Januari-Maret 2012.

\section{Hasil}

Subjek penelitian terdiri atas 30 ekor tikus strain Wistar yang telah melewati masa adaptasi di laboratorium selama tujuh hari, memenuhi kriteria inklusi, dan tidak memenuhi kriteria eksklusi. Hasil penelitian efek imunostimulan ekstrak etanol umbi iles-iles dilaksanakan membandingkan dengan kontrol positif (zymosan A) dan kontrol negatif (akuades). Setelah hasil penelitian terkumpul, kemudian dilaksanakan pengolahan data dengan analisis awal dilakukan pengujian distribusi data, kemudian selanjutnya dilakukan analisis uji ANOVA untuk melihat ada tidaknya perbedaan efek perlakuan yang diberikan antara kelompok kontrol positif dan kelompok kontrol negatif. Jika hasil uji tersebut bermakna maka dilanjutkan dengan multiple comparison mempergunakan Metode Bonferroni $(p<0,05)$. Untuk melengkapi hasil perbandingan antara kelima kelompok pengamatan, dibuat penggambaran grafis ke dalam diagram batang dan rata-rata setiap variabel.

Ekstraksi $20 \mathrm{~kg}$ umbi iles-iles dengan metode perkolasi yang menghasilkan 156,1297 g ekstrak

\section{Tabel 1 Karakteristik Ekstrak Etanol Umbi} Iles-iles

\begin{tabular}{lc}
\hline \multicolumn{1}{c}{ Parameter } & Ekstrak Etanol \\
\hline Kadar air (\%) & 8,0 \\
Kadar karbohidrat (\%) & 85 \\
Kadar protein (\%) & 7,0 \\
\hline
\end{tabular}

Tabel 2 Golongan Senyawa Kimia pada Ekstrak Etanol Umbi Iles-Iles

\begin{tabular}{lc}
\hline Kandungan Kimia & Ekstrak Etanol Umbi Iles-iles \\
\hline Alkaloid & + \\
Flavonoid & + \\
Saponin & + \\
Tanin & - \\
Kuinon & - \\
Triterpenoid & + \\
\hline
\end{tabular}

Keterangan: + = terdeteksi; - = tidak terdeteksi

pasta. Hasil penapisan fitokimia menunjukkan bahwa ekstrak umbi iles-iles itu mengandung protein, karbohidrat, alkaloid, saponin, dan triterpenoid (Tabel 1). Alkaloid dan triterpenoid merupakan senyawa berbobot molekul rendah serta polisakarida yang merupakan komponen penyusun karbohidrat yang dapat berpotensi sebagai imunostimulan. Hasil telaah fitokimia ekstrak etanol umbi iles-iles memperlihatkan bahwa ekstrak itu mengandung senyawa yang berpotensi menstimulasi sistem imun.

Tabel 1 memperlihatkan bahwa kandungan utama pada ekstrak etanol umbi iles-iles yang dipakai dalam penelitian ini adalah karbohidrat, yaitu $85 \%$. Karakteristik ekstrak etanol umbi iles-iles dapat dijelaskan pada Tabel 1.

Pada Tabel 2 terlihat bahwa hasil penapisan fitokimia yang terdapat pada ekstrak etanol umbi iles-iles adalah alkaloid, saponin, dan triterpenoid. Karakteristik golongan senyawa kimia yang terdapat pada ekstrak etanol umbi iles-iles dapat dijelaskan pada Tabel 2.

Jumlah makrofag antarkelompok rata-rata meningkat setiap jamnya; jumlah makrofag kelompok A (ekstrak etanol umbi iles-iles dosis $220 \mathrm{mg} / \mathrm{kgBB}$ ) lebih tinggi dibanding dengan kelompok B dan C serta kelompok kontrol positif (D) maupun kontrol negatif (E). Jumlah makrofag rata-rata antarkelompok dapat dilihat hasil signifikansi yang bermakna $(\mathrm{p}<0,05)$ setelah 1 , 3, dan 6 jam inokulasi S. aureus. Ekstrak etanol umbi iles-iles mampu meningkatkan jumlah makrofag secara bermakna $(p=0,001)$.

Analisis dilanjutkan dengan Uji Bonferonni untuk dapat melihat perbedaan masing-masing kelompok dibanding dengan kontrol. Selisih rata-rata paling tinggi terlihat pada kelompok zymosan dan bermakna $(\mathrm{p}<0,05)$ dibanding dengan kontrol. Kelompok ketiga dosis memiliki selisih rata-rata yang juga bermakna $(p<0,05)$ dibanding dengan kontrol. Peningkatan jumlah makrofag dapat memberikan gambaran efek ekstrak etanol umbi iles-iles terhadap respons 


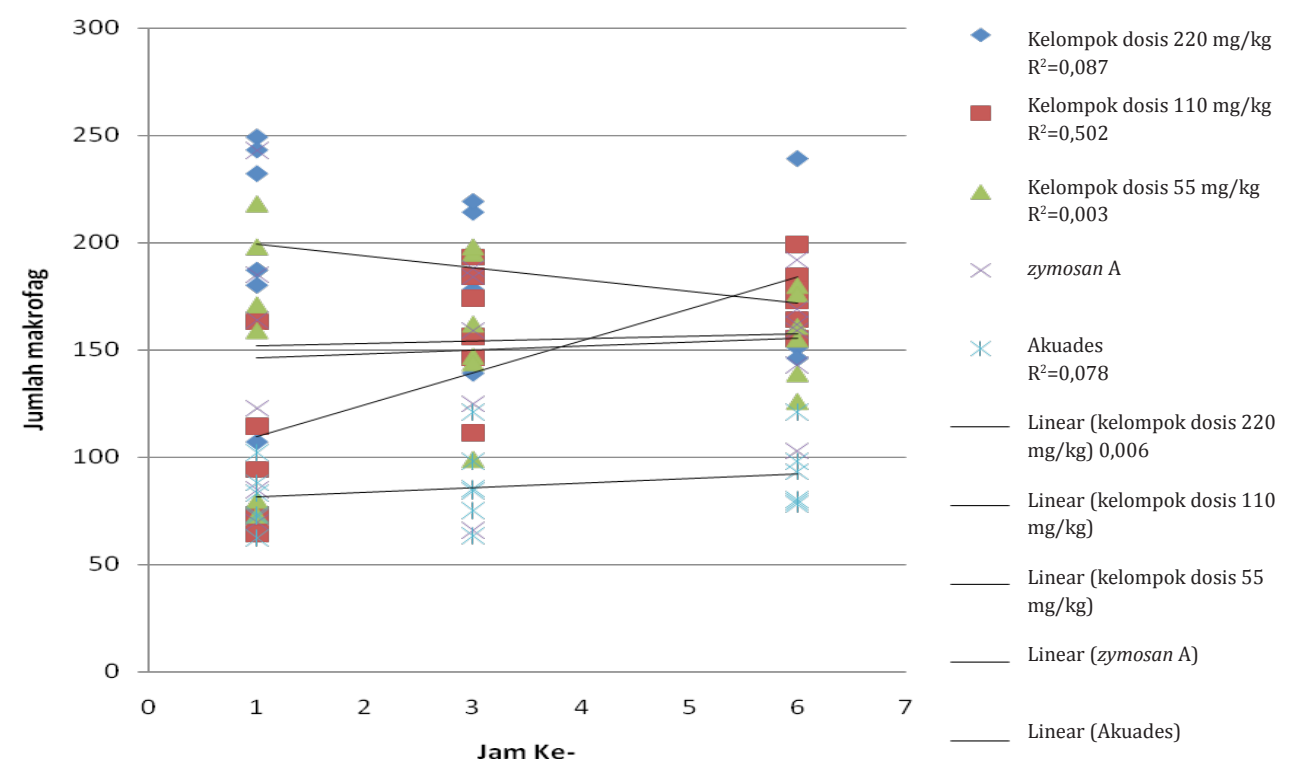

Gambar 1 Perbedaan Jumlah Makrofag Rata-Rata Antarkelompok Setelah 1, 3, dan 6 Jam Keterangan: ekstrak etanol iles-iles $220 \mathrm{mg} / \mathrm{kgBB}, \mathrm{y}=8,152-0,027 \mathrm{x}$; Ekstrak etanol iles-iles $110 \mathrm{mg} /$ kgBB, y = -1,524 + 0,034x; ekstrak etanol iles-iles $55 \mathrm{mg} / \mathrm{kgBB}, \mathrm{y}=150,728+1,132 \mathrm{x}$; zymosan A $35 \mathrm{mg} /$ kgBB (kontrol positif), $y=126,702+15,456 x$; akuades (kontrol negatif), $y=78,991+2,219 x ; y$ adalah jumlah makrofag, $\mathrm{x}$ adalah waktu

imun. Hal ini disebabkan karena memengaruhi sintesis sumsum tulang untuk menghasilkan selsel leukosit maupun sel darah merah. ${ }^{13}$

Efek ekstrak etanol umbi iles-iles terhadap jumlah makrofag dapat dijelaskan pada grafik hubungan antara waktu dan jumlah makrofag. Apabila dilihat pada jumlah makrofag akibat pemberian ekstrak etanol umbi iles-iles (Gambar 1), kemiringan garis yang paling tajam terjadi pada perlakuan kelompok A (dosis $220 \mathrm{mg} /$ kgBB) dan diikuti oleh kelompok B, C, D, dan E. Hal ini menunjukkan bahwa semua dosis ekstrak etanol umbi iles-iles dapat mengeliminasi jumlah makrofag cukup cepat dalam setiap waktunya walaupun kecepatannya masih di bawah kelompok A (dosis $220 \mathrm{mg} / \mathrm{kgBB}$ ). Gabungan nilai kuadrat $\mathrm{R}$ dan grafik linearitas pada tiap kelompok terlihat pada Gambar 1.

Jumlah makrofag rata-rata setelah 1 jam pada kelompok ekstrak etanol umbi iles-iles 220 mg/kgBB (A) adalah 199,67; kelompok ekstrak etanol umbi iles-iles $110 \mathrm{mg} / \mathrm{kgBB}$ (B) adalah 96,67; kelompok ekstrak etanol umbi iles-iles 55 mg/kgBB (C) adalah 149,83; kelompok kontrol positif (D) adalah 145; dan kelompok kontrol negatif (E) adalah 80. Jumlah makrofag rata-rata setelah 3 jam pada kelompok ekstrak etanol umbi iles-iles $220 \mathrm{mg} / \mathrm{kgBB}(\mathrm{A})$ adalah 188; kelompok ekstrak etanol umbi iles-iles $110 \mathrm{mg} / \mathrm{kgBB}$ (B) adalah 160,67; kelompok ekstrak etanol umbi iles-iles $55 \mathrm{mg} / \mathrm{kgBB}$ (C) adalah 157,5; kelompok kontrol positif (D) adalah 168,33; dan kelompok kontrol negatif (E) adalah 87,67.

Jumlah makrofag rata-rata setelah 6 jam pada kelompok ekstrak etanol umbi iles-iles $220 \mathrm{mg} /$ kgBB (A) adalah 176,167; kelompok ekstrak etanol umbi iles-iles $110 \mathrm{mg} / \mathrm{kgBB}$ (B) adalah 175,5; kelompok ekstrak etanol umbi iles-iles $55 \mathrm{mg} / \mathrm{kgBB}$ (C) 156,167; kelompok kontrol positif (D) 121,33; dan kelompok kontrol negatif (E) 91,5. Berdasarkan data tersebut, terlihat jumlah makrofag rata-rata setelah 1, 3, dan 6 jam pada kelompok A lebih besar dibanding dengan kelompok B, C, D dan E. Dari hasil analisis didapatkan perbedaan jumlah makrofag rata-rata pada kelima kelompok perlakuan. Hasil tersebut kemudian diuji dengan tingkat kepercayaan 95\% $(\mathrm{p}<0,05)$ dan didapatkan hasil berbeda secara bermakna setelah 1, 3, dan 6 jam. Hasil Uji Bonferroni menunjukkan perbedaan jumlah makrofag secara bermakna di antara 5 kelompok. Aktivitas fagositosis makrofag eksudat peritoneal tikus dievaluasi dengan melihat kemampuannya dalam memakan $S$. aureus sebagai bakteri uji. Eksudat peritoneal terdiri atas $90 \%$ makrofag dan sisanya monosit serta sel-sel lainnya. Efek ekstrak etanol umbi iles-iles pada uji aktivitas fagositosis makrofag eksudat peritoneal tikus dapat dijelaskan pada Tabel 3. 
Tabel 3 Indeks Fagositosis Setelah 1, 3, dan 6 Jam Inokulasi S. aureus

\begin{tabular}{clcc}
\hline Waktu & \multicolumn{1}{c}{ Kelompok Perlakuan } & N & Indeks Fagositosis \\
\hline \multirow{2}{*}{ J Jam } & Ekstrak Iles-iles dosis $220 \mathrm{mg} / \mathrm{kg}$ & 6 & $(80.83 \pm 2.791)$ \\
& Ekstrak Iles-iles dosis $110 \mathrm{mg} / \mathrm{kg}$ & 6 & $(57.98 \pm 10.57)$ \\
& Ekstrak Iles-iles dosis $55 \mathrm{mg} / \mathrm{kg}$ & 6 & $(59.03 \pm 3.902)$ \\
& Zymosan A $35 \mathrm{mg} / \mathrm{kg}$ & 6 & $(64.69 \pm 5.278)$ \\
& Akuades & 6 & $(67.21 \pm 4.092)$ \\
& Ekstrak Iles-iles dosis $220 \mathrm{mg} / \mathrm{kg}$ & 6 & $(85.23 \pm 2.587)$ \\
& Ekstrak Iles-iles dosis $110 \mathrm{mg} / \mathrm{kg}$ & 6 & $(77.59 \pm 4.106)$ \\
& Ekstrak Iles-iles dosis $55 \mathrm{mg} / \mathrm{kg}$ & 6 & $(72.33 \pm 1.120)$ \\
& Zymosan A $35 \mathrm{mg} / \mathrm{kg}$ & 6 & $(72.66 \pm 2.875)$ \\
& Akuades & 6 & $(92.14 \pm 2.369)$ \\
& Ekstrak Iles-iles dosis $220 \mathrm{mg} / \mathrm{kg}$ & 6 & $(79.69 \pm 2.5850)$ \\
& Ekstrak Iles-iles dosis $110 \mathrm{mg} / \mathrm{kg}$ & 6 & $(86.67 \pm 2.587)$ \\
& Ekstrak Iles-iles dosis $55 \mathrm{mg} / \mathrm{kg}$ & 6 & $(79.51 \pm 1.600)$ \\
\hline
\end{tabular}

Indeks fagositosis rata-rata antarkelompok, setelah 1, 3, dan 6 jam inokulasi $S$. aureus $(\mathrm{p}<0,05)$. Ekstrak etanol umbi iles-iles dapat meningkatkan indeks fagositosis itu secara bermakna $(p=0,001)$. Peningkatan pada indeks fagositosis dapat memberikan gambaran efek ekstrak etanol umbi iles-iles terhadap respons imun. Hal ini disebabkan oleh kandungan umbi iles-iles seperti flavonoid dan juga polisakarida yang mampu berperan sebagai imunostimulan sehingga meningkatkan aktivitas metabolisme di dalam sel makrofag. Peningkatan metabolisme di dalam sel akan meningkatkan enzim-enzim dan bahan lain yang berperan dalam fagositosis sehingga kemampuan fagositosis akan semakin meningkat. ${ }^{14}$

Setelah satu jam inokulasi $S$. aureus, indeks fagositosis rata-rata pada kelompok ekstrak etanol umbi iles-iles $220 \mathrm{mg} / \mathrm{kgBB}$ (A) adalah
80,8333; kelompok ekstrak etanol umbi iles-iles $110 \mathrm{mg} / \mathrm{kgBB}$ (B) adalah 57,9833; kelompok ekstrak etanol umbi iles-iles $55 \mathrm{mg} / \mathrm{kgBB}$ (C) adalah 59,0317; kelompok kontrol positif (D) adalah 64,9667; dan kelompok kontrol negatif (E) adalah 67,2133. Setelah 3 jam inokulasi $S$. aureus, indeks fagositosis rata-rata pada kelompok ekstrak etanol umbi iles-iles $220 \mathrm{mg} /$ kgBB (A) adalah 85,2367; kelompok ekstrak etanol umbi iles-iles $110 \mathrm{mg} / \mathrm{kgBB}$ (B) adalah 62,7167; kelompok ekstrak etanol umbi ilesiles 55 mg/kgBB (C) 77,5950; kelompok kontrol positif (D) 72,3333; dan kelompok kontrol negatif (E) adalah 72,6667. Setelah 6 jam inokulasi $S$. aureus, indeks fagositosis rata-rata pada kelompok ekstrak etanol umbi iles-iles 220 $\mathrm{mg} / \mathrm{kgBB}(\mathrm{A})$ adalah 92,1433; kelompok ekstrak etanol umbi iles-iles $110 \mathrm{mg} / \mathrm{kgBB}$ (B) 85,2367; kelompok ekstrak etanol umbi iles-iles $55 \mathrm{mg} /$

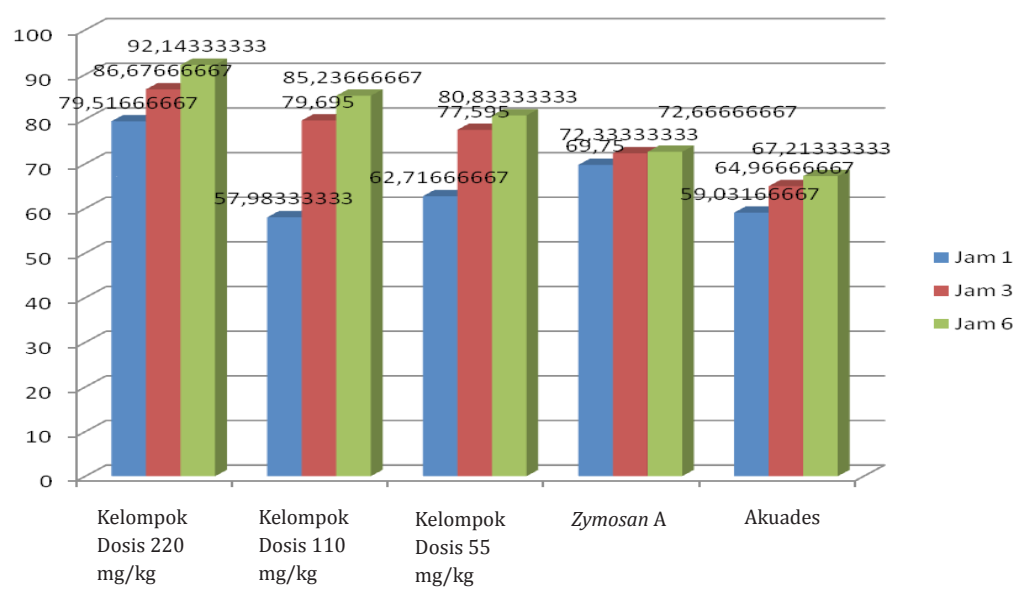

Gambar 2 Perbedaan Indeks Fagositosis Rata-rata Antarkelompok Setelah 1, 3, dan 6 Jam 
Arfatul: Efek Imunostimulasi Ekstrak Etanol Umbi Iles-iles Terhadap Aktivitas Fagositosis Sel Makrofag pada Tikus Putih

Tabel 4 Indeks Organ Setelah 1, 3, dan 6 Jam Inokulasi S. aureus

\begin{tabular}{clcc}
\hline \multicolumn{1}{c}{ Organ } & \multicolumn{1}{c}{ Kelompok Perlakuan } & N & Indeks Fagositosis \\
\hline Hati & Ekstrak Iles-iles dosis $220 \mathrm{mg} / \mathrm{kg}$ & 6 & $(3,23 \pm 0,52)$ \\
& Ekstrak Iles-iles dosis $110 \mathrm{mg} / \mathrm{kg}$ & 6 & $(3,18 \pm 0,19)$ \\
& Ekstrak Iles-iles dosis $55 \mathrm{mg} / \mathrm{kg}$ & 6 & $(3,05 \pm 0,22)$ \\
& Zymosan A $35 \mathrm{mg} / \mathrm{kg}$ & 6 & $(2,15 \pm 0,17)$ \\
& Akuades & 6 & $(3,17 \pm 0,34)$ \\
Limpa & Ekstrak Iles-iles dosis $220 \mathrm{mg} / \mathrm{kg}$ & 6 & $(0,42 \pm 0,11)$ \\
& Ekstrak Iles-iles dosis $110 \mathrm{mg} / \mathrm{kg}$ & 6 & $(0,22 \pm 0,10)$ \\
& Ekstrak Iles-iles dosis $55 \mathrm{mg} / \mathrm{kg}$ & 6 & $(0,34 \pm 0,04)$ \\
& Zymosan A $35 \mathrm{mg} / \mathrm{kg}$ & 6 & $(0,28 \pm 0,13)$ \\
Timus & Akuades & 6 & $(0,36 \pm 0,05)$ \\
& Ekstrak Iles-iles dosis $220 \mathrm{mg} / \mathrm{kg}$ & 6 & $(0,37 \pm 0,09)$ \\
& Ekstrak Iles-iles dosis $110 \mathrm{mg} / \mathrm{kg}$ & 6 & $(0,28 \pm 0,09)$ \\
& Ekstrak Iles-iles dosis $55 \mathrm{mg} / \mathrm{kg}$ & 6 & $(0,30 \pm 0,08)$ \\
& Zymosan A $35 \mathrm{mg} / \mathrm{kg}$ & 6 & $(0,31 \pm 0,09)$ \\
& Akuades & 6 & $(0,18 \pm 0,11)$ \\
\hline
\end{tabular}

kgBB (C) 79,6950; kelompok kontrol positif (D) 86,6767; dan kelompok kontrol negatif (E) adalah 79,5167. Berdasarkan data tersebut, terlihat indeks fagositosis rata-rata setelah 1, 3, dan 6 jam pada kelompok A lebih besar dibanding dengan kelompok B, C, D, dan E. Hasil Uji Bonferroni menunjukkan perbedaan indeks fagositosis yang bermakna antara 5 kelompok. Hasil tersebut kemudian diuji dengan tingkat kepercayaan 95\% $(\mathrm{p}<0.05)$ dan didapatkan hasil berbeda secara bermakna setelah 1, 3, dan 6 jam.

Hal ini disebabkan komponen bioaktif pada umbi iles-iles dapat meningkatkan aktivitas makrofag untuk memakan benda asing dalam hal ini $S$. aureus sehingga akan menyebabkan proses fagositosis di dalam makrofag yang menyebabkan lisisnya sel bakteri. B-D-glucans dapat mengaktivasi peritoneal makrofag seperti enzim lisosom, aktivitas fagositik, dan produksi $\mathrm{H}_{2} \mathrm{O}_{2}$. Makrofag mengenali B-D-glucans melalui reseptor TLR-2 atau komplemen reseptor 3 (CR3) yang dinotasikan sebagai gabungan CD11 b/CD18 dan MAC1 yang merupakan salah satu bagian dari pattern recognition receptors (PRR). Ikatan B-D-glucans dengan CR3 secara langsung akan menjadi pemicu untuk proses fagositosis. ${ }^{15}$

Data perbedaan indeks fagositosis rata-rata antarkelompok, dapat dilihat pada Gambar 2 . Hasil percobaan memperlihatkan peningkatan indeks fagositosis bakteri sangat bermakna $(\mathrm{p}<0,001)$ pada ketiga dosis ekstrak etanol umbi iles-iles, kelompok zymosan $A$ (kontrol positif), dan kelompok akuades (kontrol negatif). Analisis dilanjutkan dengan Metode Bonferroni untuk melihat perbedaan masing-masing kelompok perlakuan dibanding dengan kontrol.
Persen indeks hati, limpa, dan kelenjar timus dapat digunakan sebagai salah satu parameter untuk menilai respons imun. Peningkatan bobot organ dinyatakan dalam persen terhadap bobot badan (\% indeks organ). Eliminasi S. aureus $90 \%$ terjadi di hati oleh sel kuffer. Peningkatan ploriferasi pada sel-sel hati, limpa, dan kelenjar timus serta bobot organ tersebut memberikan indikasi meningkatnya respons imun, sebaliknya penurunan bobot organ tersebut berarti juga penurunan respons imun. Efek ekstrak etanol umbi iles-iles terhadap indeks organ dapat dilihat pada Tabel 4 .

Pada Tabel 4 dapat dilihat bahwa indeks organ hati, limpa, serta kelenjar timus pada semua kelompok ekstrak etanol umbi iles-iles tidak bermakna dibanding dengan kontrol. Hal ini terjadi karena mekanisme umpan balik tubuh terhadap penekanan sistem imun sehingga pemberian ekstrak memengaruhi produksi selsel kuffer maupun organ limfoid sekunder dalam reaksi fagositosis partikel asing. ${ }^{6}$

Indeks organ hati rata-rata pada kelompok ekstrak etanol umbi iles-iles $220 \mathrm{mg} / \mathrm{kgBB}$ (A) adalah 3,23; kelompok ekstrak etanol umbi ilesiles $110 \mathrm{mg} / \mathrm{kgBB}$ (B) 3,18; kelompok ekstrak etanol umbi iles-iles $55 \mathrm{mg} / \mathrm{kgBB}$ (C) 3,05; kelompok kontrol positif (D) 2,15; dan kelompok kontrol negatif (E) 3,17.

Indeks organ limpa rata-rata pada kelompok ekstrak etanol umbi iles-iles $220 \mathrm{mg} / \mathrm{kgBB}$ (A) adalah 0,420; kelompok ekstrak etanol umbi iles-iles $110 \mathrm{mg} / \mathrm{kgBB}$ (B) 0,225; kelompok ekstrak etanol umbi iles-iles $55 \mathrm{mg} / \mathrm{kgBB}$ (C) 0,345; kelompok kontrol positif (D) 0,282; dan kelompok kontrol negatif (E) 0,362. Indeks rata- 
rata organ antarkelompok dapat meningkat setiap jamnya. Hasil tersebut kemudian diuji dengan tingkat kepercayaan 95\% $(\mathrm{p}<0.05)$ dan didapatkan hasil berbeda bermakna setelah inokulasi $S$. aureus.

Indeks organ timus rata-rata pada kelompok ekstrak etanol umbi iles-iles $220 \mathrm{mg} / \mathrm{kgBB}$ (A) adalah 0,371; kelompok ekstrak etanol umbi iles-iles $110 \mathrm{mg} / \mathrm{kgBB}$ (B) adalah 0,28; kelompok ekstrak etanol umbi iles-iles $55 \mathrm{mg} /$ kgBB (C) 0,308; kelompok kontrol positif (D) 0,31; dan kelompok kontrol negatif (E) 0,182. Berdasarkan data tersebut terlihat indeks organ hati, limpa, dan timus rata-rata pada kelompok A lebih besar dibanding dengan kelompok B, C, D, dan E. Hasil Uji Bonferroni menunjukkan perbedaan indeks organ timus secara bermakna antara 5 kelompok.

\section{Pembahasan}

Peningkatan jumlah enzim yang terdapat dalam makrofag berhubungan dengan kemampuan digesti intraseluler material yang difagosit, perkembangan dan mampu mempertahankan reaksi radang, serta pembunuhan kuman. ${ }^{5}$ Enzim lisozim yang dilepaskan akan menghidrolisis peptidoglikan dinding sel-sel kuman. Enzimenzim yang lain seperti ribonuklease, protease, deoksiribonuklease, lipase, dan rafinose akan menghidrolisis komponen-komponen kuman. Pada uji ANOVA terlihat perbedaan pada setiap kelompok perlakuan $(\mathrm{p}<0,05)$. Ekstrak etanol umbi iles-iles dosis $220 \mathrm{mg} / \mathrm{kgBB}$ mempunyai jumlah makrofag, indeks fagositosis, dan indeks organ terbesar dibanding dengan kelompok ekstrak etanol umbi iles-iles dosis $110 \mathrm{mg} /$ $\mathrm{kgBB}$, dosis $55 \mathrm{mg} / \mathrm{kgBB}$, pembanding zymosan A, serta kelompok kontrol (akuades). Hasil memperlihatkan ekstrak etanol umbi iles-iles dosis $220 \mathrm{mg} / \mathrm{kgBB}$ dapat meningkatkan jumlah dan aktivitas fagositosis sel makrofag pada tikus yang diinokulasi $S$. aureus. ${ }^{6}$ Peningkatan fagositosis tersebut disebabkan oleh banyaknya antigen yang berfungsi sebagai induktor untuk dapat meningkatkan fungsi fagositosis makrofag. Peningkatan aktivitas makrofag itu sesudah pemberian ekstrak etanol umbi iles-iles tersebut disebabkan oleh peningkatan sekret sitokin yang dihasilkan oleh sel-sel imunokompeten, antara lain interleukin-1 dan interleukin-6. Terdapat sitokin-sitokin yang merupakan pengaktif sel makrofag maka aktivitas fagositosis makrofag dapat ditingkatkan. ${ }^{12}$

Makrofag teraktivasi oleh antigen yang masuk ke dalam tubuh, senyawa flavonoid dan polisakarida murni dapat direspons dengan baik oleh sistem imun tubuh. Ekstrak etanol umbi iles-iles mengandung senyawa flavonoid dan polisakarida yang dapat meningkatkan sistem imun, yaitu meningkatkan aktivitas sel makrofag. 5,14

S. aureus akan menstimulasi makrofag untuk memproduksi IL-6 yang akan mengaktifkan sel NK yang kemudian akan menyekresi IFN- $\beta$ yang akan mengaktifkan makrofag. Makrofag juga akan terstimulasi untuk memproduksi TNF- $\alpha$ yang akan mengaktivasi makrofag lainnya. Aktivitas imunostimulan ditunjukkan dengan peningkatan indeks organ hati, limpa, dan timus. $^{15}$

Gambaran mikroskopis pada penelitian ini adalah makrofag terutama berasal dari sel prekursor pada sumsum tulang, dari promonosit yang akan membelah menghasilkan monosit yang beredar dalam darah. Pada tahap kedua monosit bermigrasi ke dalam jaringan ikat tempat mereka menjadi matang dan inilah yang disebut makrofag. Di dalam jaringan makrofag dapat berproliferasi secara lokal menghasilkan sel sejenis lebih banyak. Sel-sel sistem makrofag terdapat pada jaringan ikat longgar berupa makrofag atau histiosit, di dalam darah berupa monosit, di dalam hati melapisi sel sinusoid dikenal sebagai sel kuffer, makrofag perivaskular sinusoid limpa, limfonodus dan juga sumsum tulang, serta pada susunan saraf pusat berupa mikroglia yang berasal dari mesoderm. ${ }^{6,13}$ Hasil pengamatan menunjukkan bahwa secara mikroskopis pada pembesaran objektif $100 \mathrm{x}$ terlihat sel makrofag eksudat peritoneal yang memfagositosis $S$. aureus (berwarna terang di dalam makrofag) setelah 1, 3, dan 6 jam>100 sel per lapang pandang. ${ }^{15}$

Berdasarkan atas hasil pengamatan aktivitas fagositosis sel makrofag yang diinokulasi $S$. aureus memperlihatkan perbedaan jumlah sel makrofag yang memfagositosis bakteri dari setiap kelompok perlakuan dosis $220 \mathrm{mg} /$ $\mathrm{kgBB}, 110 \mathrm{mg} / \mathrm{kgBB}, 55 \mathrm{mg} / \mathrm{kgBB}$, pembanding zymosan $A$ dan kelompok kontrol (akuades). Hasil analisis statistik menunjukkan bahwa masing-masing ekstrak yang ditambahkan akan memberikan pengaruh yang bermakna terhadap peningkatan aktivitas fagositosis sel makrofag $(p<0,05)$. Preparat apus dari masing-masing perlakuan dihitung aktivitas fagositosis (SFA). Hasil yang diperoleh dibanding dengan kontrol positif (zymosan $A$ ) maupun kontrol negatif (akuades). Bila nilai indeks fagositosis kelompok perlakuan lebih besar daripada kelompok 
kontrol, mengidentifikasikan efek stimulasi atau peningkatan aktivitas fagositosis oleh bahan uji. ${ }^{15}$ Flavonoid, saponin, dan polisakarida yang terkandung dalam ekstrak etanol umbi iles-iles telah terbukti memiliki efek anti-inflamasi. Hal tersebut ditunjang oleh penelitian sebelumnya oleh Khan dkk. ${ }^{3,4}$ yang melihat umbi iles-iles sebagai antibakteri, antifungal, dan sitotoksik serta juga anti-inflamasi pada tikus putih yang memperlihatkan bahwa umbi iles-iles memiliki efek anti-inflamasi.

Berdasarkan hasil dan pembahasan dapat diambil simpulan bahwa ekstrak etanol umbi iles-iles meningkatkan jumlah sel makrofag tikus putih strain Wistar terhadap S. aureus sebagai mikrob uji, meningkatkan aktivitas fagositosis sel makrofag tikus putih strain Wistar, dan semakin tinggi konsentrasi dosis ekstrak etanol umbi iles-iles maka semakin meningkat jumlah dan aktivitas fagositosis sel makrofag pada tikus putih strain Wistar yang diinokulasi S. aureus.

\section{Daftar Pustaka}

1. Abbas AK, Lichtman AH, Pober JS. Innate immunity. Dalam: Schmitt W, penyunting. Cellular and molecular immunology. Edisi ke-4. Philadelphia: WB Saunders Co; 2007. hlm. 19-71.

2. Aggarwal S, Moodley, YP Thompson PJ, Misso NL. Prostaglandin $E_{2}$ and cysteinyl leukotriene concentrations in sputum: association with asthma severity and eosinophilic inflammation. Clin Experimental Allergy. 2009;40(5):85-93.

3. Khan A, Rahman M, Islam MS. Antibacterial, antifungal and cytotoxic activities of tuberous roots of Amorphophallus campanulatus. J Biol Turk. 2007;31:167-72.

4. Khan A, Rahman M, Islam MS. Antibacterial, antifungal and cytotoxic activities of amblyone isolated from Amorphophallus campanulatus. Indian J Pharmacol. 2008; 40(1):41-4.

5. Ambarwati E, Murti RH. Analisis korelasi dan koefisien lintas sifat-sifat agronomi terhadap komposisi kimia umbi iles-iles (Amorphophallus variabilis). Jurnal Ilmu Pertanian. 2001;8(2):55-61.

6. Baratawidjaja KG, Rengganis I. Sel-sel sistem imun nonspesifik, sistem fagosit makrofag. Dalam: Wachjuni, Ambara, Prasna P, Farah $\mathrm{P}$, penyunting. Imunologi dasar. Edisi ke9. Jakarta: Balai Penerbit FKUI; 2010. hlm.
57-90.

7. Nah SS, Choi IY, Lee CK, Oh JS, Kim YG, Moon HB, Yoo, dkk. Effects of advanced glycation and products on the expression of COX2, PGE2 and NO in human osteoarthritic chondrocytes. J Rheumatol. 2008;47(4):42531.

8. Franca ACH, Eduardo LF, Joanna CM, Valeria CC, Uender CRP, Claudemir B. Immunomodulatory effects of herbal plants plus melatonin on human blood phagocytes. Internat J Phytomed. 2010;2:354-62.

9. Kusmardi, Kumala S, Wulandari D. Pengaruh pemberian ekstrak etanol daun johar (Cassia siamea Lamk.) terhadap peningkatan aktivitas dan kapasitas fagositosis sel makrofag. J Makara Kesehatan. 2006;10(2):89-93.

10. Kusmardi, Kumala S, Triana EE. Efek immunomodulator ekstrak daun ketepeng cina (Cassia allata L.) terhadap aktivitas dan kapasitas fagositosis makrofag. J Makara Kesehatan. 2007;11(2):50-3.

11. Jain S, DixidVK, Malviya N, VijayA.Antioxidant, anti inflammation and hepatoprotective activity of etanolic and aqueous extracts of Amorphophallus campanulatus. Roxb. Tubers. Acta Poloniae Pharmaceutica-Drug Research. 2009;66(4):423-8.

12. Sudibyo ES, Rohmawati E, Munira, Febriana SA, Radiono S, Suswanto. Profil resistensi pada Staphylococcus aureus dan Pseudomonas aeruginosa. Berkala Kesehatan Klinik. 2008;14(2):98-102.

13. Shao J, Jung C, Liu C, Sheng H. Prostaglandin $\mathrm{E}_{2}$ stimulates the $\beta$-Catenin/T cell factordependent transcription in colon cancer. J Biol Chem. 2005;280(28):26565-72.

14. Sumarwoto. Pengaruh pemberian kapur dan ukuran bulbil terhadap pertumbuhan iles-iles (Amorphophallus muelleri) pada tanah ber-Al tinggi. Jurnal Ilmu Pertanian. 2004;2(2):45-53.

15. Umbrain VJ, Lauwers MH, Shi L, Smolders I, Michotte Y, Poelaert J. Comparison of the effects of intrathecal administration of levobupivacaine and lidocaine on the prostaglandin $\mathrm{E}_{2}$ and glutamate increases in cerebrospinal fluid: a microdialysis study in freely moving rats. Br J Anaesth. 2009; 102(4):540-5. 